\title{
THE EXCEPTIO NON ADIMPLETI CONTRACTUS IN PUBLIC INTERNATIONAL LAW
}

\begin{abstract}
The position of the exceptio non adimpleti contractus in public international law as a response to the breach of a treaty is surrounded by uncertainty. The present article aims to offer an analytical examination of I) the notion of the exceptio and its relationship to other responses to the breach of a treaty; II) the question of its conditions of application; and III) its character as a rule of international law. It argues that the exceptio is distinct both from responses according to Art 60 VCLT and from countermeasures; however, there is still uncertainty with regard to its conditions of application. It can be considered as a general principle of law and, as such, it can fill gaps in the regulation of responses to the breach of a treaty. However, it is not clear whether the exceptio constitutes a rule of customary international law.
\end{abstract}

Keywords: exceptio non adimpleti contractus; exception of non-performance; breach of treaty; synallagmatic obligations

\section{Introduction}

The notion of the exceptio non adimpleti contractus in public international law remains disputed. It is unclear not only whether it belongs to the law of treaties or the law of State responsibility, but also whether it is a rule of international law and what are its conditions of application. This article purports to clarify the notion of the exceptio and its relationship to other responses to the breach of a treaty (Section 2), as well as its conditions of application (Section 3), and attempts to answer the question of whether it is a rule of current international law through an examination of the sources of international law according to Art 38 of the Statute of the International Court of Justice (Section 4). The findings of this analysis are summarised in the conclusion (Section 5). 


\title{
2 The Notion of the Exceptio Non Adimpleti Contractus in Public International
}

Law and its Relationship to Other Responses to the Breach of a Treaty

\author{
2.1 The Notion of the Exceptio Non Adimpleti Contractus in Public International \\ Law
}

The exceptio non adimpleti contractus (also referred to as exceptio or exception of non-performance $)^{1}$ is, as the term exceptio denotes, a means of legal defence ${ }^{2}$ according to which a party to a treaty can withhold performance of an obligation arising therefrom for so long as the other party has not performed a synallagmatic (derived from the Greek word $\sigma v v \alpha \dot{\lambda} \lambda \lambda \alpha \gamma \mu \alpha$, which in antiquity had the meaning of contract or covenant) obligation under the treaty; in such a case, the one obligation constitutes an exchange for the other. The exceptio stems from the broader principle inadimplenti non est adimplendum, ${ }^{3}$ according to which a party to a treaty need not perform its obligations under that treaty if the other party to the treaty does not perform its own obligations. Actually, there is often confusion between the exceptio and the broader principle; ${ }^{4}$ however, the principle inadimplenti non est adimplendum is considered as encompassing, apart from the exceptio non adimpleti contractus, other responses to the breach of a treaty, which are not restricted to synallagmatic obligations, namely the termination or the suspension of the operation of a treaty in whole or in part in response to its material breach, according to Art 60 of the 1969 Vienna Convention on the Law of Treaties ('VCLT'). ${ }^{5}$

\footnotetext{
${ }^{1}$ See generally James Crawford and Simon Olleson, “The Exception of Non-Performance: Links between the Law of Treaties and the Law of State Responsibility”, 21 AustYBIL (2000) pp. 55-74; DW Greig, "Reciprocity, Proportionality and the Law of Treaties", 34 VJIL (1994) pp. 295-403; Joseph Nisot, “L'exception 'Non Adimpleti Contractus' en Droit International”, 74 RGDIP (1970), pp. 668-73; Danae Azaria, "Exception of Non-Performance”, MPEPIL online (last updated February 2015) <http://opil.ouplaw.com/view/10.1093/law:epil/9780199231690/law-9780199231690e2130?rskey=vScKtx\&result=1\&prd=EPIL $>$ accessed 18 April 2018.

${ }^{2}$ Georges Ripert, “Les Règles du Droit Civil Applicables aux Rapports Internationaux”, 44 Recueil des Cours de l’Académie de Droit International (1933) p. 605; Nisot (n 1) p. 668.

${ }^{3}$ International Law Commission, 'Report of the International Law Commission on the work of its 55 $5^{\text {th }}$ session’ (3 May-23 July 1999) UN Doc A/54/10 ('ILC Report 1999'), p. 79 para 341; Separate Opinion of Judge Simma, Application of the Interim Accord of 13 September 1995 (the Former Yugoslav Republic of Macedonia v Greece) [2011] ICJ Rep 695 para 17.

${ }^{4}$ See for example Pleadings by France, Air Service Agreement of 27 March 1946 between the United States of America and France case (1978) 18 RIAA 417 para 17; Special Rapporteur Riphagen, Preliminary report on the content, forms and degrees of international responsibility, ILCYB 1980-II ('Riphagen I’), p. 118 para 58.

${ }^{5}$ Adopted 23 May 1969, entered into force 27 January 1980 (1155 UNTS 331). See Bruno Simma, "Reflections on Article 60 of the Vienna Convention on the Law of Treaties and Its Background in
} 
The principle inadimplenti non est adimplendum is itself crystallisation of the negative aspect of the general principle of reciprocity, ${ }^{6}$ which justifies a response affecting an obligation identical or equivalent to that breached. In Art 60 VCLT this is to a certain extent reflected in the requirement that the treaty which is terminated or the operation of which is suspended must be the same as that which is materially breached. Of course, according to the letter of Art 60 VCLT, in case of partial termination or suspension of the operation of a treaty, the provision which is terminated or the operation of which is suspended need not necessarily be the one which has been materially breached, but can be another provision of the same treaty, ${ }^{7}$ contrary to the exceptio, which only permits the non-performance of an obligation corresponding to that which is not performed by the other party. The exceptio is therefore a corollary of the principle of reciprocity ${ }^{8}$ in its strictest version.

\subsection{The Exceptio in the Work of the International Law Commission}

The question whether the exceptio non adimpleti contractus should be included among responses to the breach of a rule of international law was posed in the codifications of both the law of treaties and the law of State responsibility by the International Law Commission ('ILC'). Nevertheless, the course of the examination of the exceptio by the ILC has been tortuous.

During the codification of the law of treaties, Special Rapporteur Fitzmaurice included in his Fourth Report the exceptio among responses to the breach of a treaty. Although he envisaged 'a general international law rule of reciprocity' operating with regard to any international obligation, regardless of its source, and justifying ' $a b$ extra, by operation of a general rule of international law' that 'the failure of one State to perform its international obligations in a particular respect, will either entitle other States to proceed to a corresponding non-performance in relation to that State, or will at any rate disentitle that State from objecting to such corresponding non-

\footnotetext{
General International Law”, 20 ÖZöR (1970) p. 20; Special Rapporteur Arangio-Ruiz, Third report on State responsibility, ILCYB 1991-II (‘Arangio-Ruiz III’) pp. 13-14.

${ }^{6}$ Michel Virally, "Le principe de réciprocité dans le droit international contemporain”, 122 Recueil des Cours de l'Académie de Droit International (1967) p. 51; Simma (n 5) p. 8.

${ }^{7}$ See also Art 44 (2) VCLT.

${ }^{8}$ Separate Opinion of Judge Simma, FYROM v Greece para 10; Dissenting Opinion of Judge ad hoc Roucounas, FYROM v Greece para 66; Elisabeth Zoller, Peacetime Unilateral Remedies: An Analysis of Countermeasures (1984) pp. 14-15; Greig (n 1) pp. 320-1.
} 
performance', he considered that the non-performance more specifically of a treaty can be justified ' $a b$ intra, by the operation of a condition which, whether it is actually expressed in a treaty or not, is deemed by international law to be implied, either in all treaties, or in the particular class to which the treaty concerned belongs'. ${ }^{9}$ He thus proposed a draft article stipulating that 'By virtue of the principle of reciprocity [...] non-performance of a treaty obligation by one party to the treaty will, so long as such non-performance continues, justify an equivalent and corresponding non-performance by the other party or parties' ${ }^{10}$ This 'equivalent and corresponding non-performance' was also included in the section 'Modalities of redress for breaches of treaty' of the same report, as distinct from the other responses to the breach of a treaty. ${ }^{11}$ Although Fitzmaurice did not use the term 'exceptio non adimpleti contractus', the response to which he refers clearly corresponds to the notion of the exceptio.

By contrast, Special Rapporteur Waldock did not deal with issues of performance of treaty obligations in his reports on the law of treaties. He seems to have equated the 'equivalent and corresponding non-performance', to which Fitzmaurice had referred, with the termination or suspension of the operation 'only of the provision which had been breached by the defaulting party'. ${ }^{12}$ This equation, on the ground that both termination or suspension of the operation of a treaty as a whole and the termination or suspension of the operation 'only of the provision which had been breached by the defaulting party' are applications of the principle inadimplenti non est adimplendum, ${ }^{13}$ does not square with the traditional meaning of the notion of the exceptio. ${ }^{14}$ As already explained, the exceptio is an aspect of the principle inadimplenti non est adimplendum different from that of termination or suspension of the operation of a treaty, and, contrary to these two responses, as it will be seen, it has the function of a defence and does not affect the force of the treaty. ${ }^{15}$

9 Special Rapporteur Fitzmaurice, Fourth report on the Law of Treaties, ILCYB 1959-II ('Fitzmaurice IV') p. 44, draft art 11 (2); ibid, p. 70 para 102 (emphasis in the text).

${ }^{10}$ Ibid, p. 46, draft art 20 (1).

${ }^{11}$ Ibid, pp. 50-1, draft art 37 (d).

12 Special Rapporteur Waldock, Second report on the Law of Treaties, ILCYB 1963-II ('Waldock II'), p. 76 para 14.

${ }^{13}$ Ibid.

${ }^{14}$ See above, Section 2.1.

${ }^{15}$ See below, Section 2.4 . 
In any event, presumably because of this equation and because of the omission of issues of performance of treaty obligations from the reports of the $\mathrm{ILC}^{16}$ the principle did not eventually find its way into the VCLT. It must however be noted that during the discussions in the ILC, several members of the Commission pointed out the omission of the exceptio from the draft articles of the ILC on the law of treaties. Bartoš referred to the 'rule do ut des' in the law of treaties, pointing out that treaties often contain provisions under which 'one State could not demand of another something that it refused to accord itself, contrary to the provisions of the treaty.... ${ }^{17}$ Furthermore, Reuter referred, separately from the suspension of the operation of a treaty, to the 'principle of reciprocity, on which the draft [the 1966 ILC draft articles] as it stood was perhaps rather reticent. ${ }^{18}$ In response to this comment, Rosenne stated that he considered that the principle of reciprocity in treaty obligations had been covered in the draft articles, but that the point raised by Reuter should be examined by the ILC. ${ }^{19}$ Such examination did not take place in either the Commission or the Vienna Conference. Thus, there was no clear agreement in the ILC that Art 60 VCLT had covered the notion of the exceptio.

However, during the codification of the law of State responsibility by the ILC there were again proposals for the inclusion of the exceptio among responses to the breach of international obligations. Special Rapporteur Riphagen in his Fourth Report initially took the position that 'the rule of reciprocity of obligations' (from which, as already seen, ${ }^{20}$ the exceptio is derived) is distinct from countermeasures, ${ }^{21}$ as well as from the suspension of the operation of a treaty. He referred to such a rule as 'reciprocity stricto sensu', 22 which justified the non-fulfilment of an obligation by a party in case of breach of a synallagmatic obligation; ${ }^{23}$ therefore it becomes clear that he referred to the exceptio. Eventually however, he considered that this notion of

\footnotetext{
${ }^{16}$ With the exception of what became Art 26 VCLT.

${ }^{17}$ ILC, Summary Record of the 692 ${ }^{\text {nd }}$ meeting, ILCYB 1963-I ('UN Doc A/CN.4/SR.692') para 30.

${ }^{18}$ ILC, Summary Record of the $848^{\text {th }}$ meeting, ILCYB 1966-I para 36.

19 Ibid, para 45.

${ }^{20}$ See above, Section 2.1.

${ }^{21}$ Special Rapporteur Riphagen, Fourth report on the content, forms and degrees of international responsibility, ILCYB 1983-II ('Riphagen IV'), pp. 17-8 para 95.

${ }^{22}$ Ibid, p. 22 para 118.

${ }^{23}$ Ibid, p. 19 para 103.
} 
reciprocity created a separate category of countermeasures and proposed a relevant draft article. ${ }^{24}$

Although he admitted that the distinction between such 'reciprocity' ${ }^{25}$ and reprisals (namely countermeasures) is a difficult one, he still thought that it had to be made in order to reflect the difference between the two responses in State practice. $^{26}$ This view received support from some members of the ILC. ${ }^{27}$ Nevertheless, it needs to be clarified that the notion of 'reciprocal countermeasures' proposed by Riphagen (contrary to his initial proposal which distinguished between 'reciprocity' and countermeasures) departs from the concept of the exceptio, which is distinct from countermeasures. ${ }^{28}$ It is interesting in this regard to cite the remark by Reuter in the discussions of the ILC: he also considered that there was no clear distinction between 'reciprocity' and 'reprisals' and noted that

...there might exist a grey area between those two concepts if the principle of exceptio non adimpleti contractus had been adopted by the Special Rapporteur; however, that principle had been eliminated, and rightly so, if only because of its highly conventional connotations. The Commission had decided that the rules to be drawn up would not be attached to the source of responsibility. ${ }^{29}$

Special Rapporteur Arangio-Ruiz also seems to have considered responses based on reciprocity as a form of countermeasures. ${ }^{30}$ Eventually, the idea of 'reciprocal countermeasures' was rejected by the ILC on the ground of the difficulty of distinction from non-reciprocal countermeasures. ${ }^{31}$ Therefore it was considered that the former did not deserve special treatment as a distinct category of countermeasures: they were viewed as a particular application of the broader concept of reciprocity which extended to various areas of international law and it was

\footnotetext{
${ }^{24}$ Special Rapporteur Riphagen, Fifth report on the content, forms and degrees of international responsibility, ILCYB 1984-II ('Riphagen V') p. 3, draft art 8.

25 The word is used in quotation marks because the notion of reciprocity, as already seen (Section 2.1), normally has a broader meaning.

${ }^{26}$ ILC, Summary Record of the $1891^{\text {st }}$ meeting, ILCYB 1985-I para 20.

27 See for example Sinclair (ILC, Summary Record of the $1895^{\text {th }}$ meeting, ILCYB 1985-I para 8). See however for instance Reuter (ILC, Summary Record of the $1771^{\text {st }}$ meeting, ILCYB 1983-I para 23).

${ }^{28}$ See below Sections 2.3 and 2.4.

${ }^{29}$ ILC, Summary Record of the $1858^{\text {th }}$ meeting, ILCYB 1984-I para 31.

${ }^{30}$ Arangio-Ruiz III, pp. 9-10 para 14; ibid, pp. 13 para 32.

${ }^{31}$ ILC, 'Report of the International Law Commission on the Work of its $37^{\text {th }}$ session' (6 May-26 July 1985) UN Doc A/40/10, p. 22 para 128.
} 
suggested that they should be dealt with in the context of proportionality. ${ }^{32}$ Indeed, in the commentary to the ASR it is stated that 'countermeasures are more likely to satisfy the requirements of necessity and proportionality if they are taken in relation to the same or a closely related obligation.... ${ }^{33}$

Special Rapporteur Crawford also rejected the notion of reciprocal countermeasures but considered that some version of the exceptio could be incorporated in Chapter $\mathrm{V}$ of the draft articles as a circumstance precluding wrongfulness. ${ }^{34}$ However he considered that there are two versions of the exceptio: ${ }^{35}$ one broader, in the sense analysed in this article; and one narrower, according to the dictum in the Factory at Chorzów case, which requires 'a causal link between the breach of the obligation by State $\mathrm{A}$ and its non-performance by State B'. ${ }^{36}$ Considering that the broader form of the exceptio was covered by the termination or suspension of a treaty according to Art 60 VCLT and by countermeasures, Crawford proposed the inclusion only of the narrow form in the ASR. ${ }^{37}$

Diverging views were expressed in the ILC with regard to the inclusion of this form of the exceptio; they did not seem to be restricted to the so-called narrow form of the exceptio but could also be considered as referring to the exceptio in its broader sense. They can be summarised as follows: first, several members of the ILC considered that the exceptio was covered by either Art $60 \mathrm{VCLT}^{38}$ or countermeasures and therefore did not need to be treated separately in the draft articles. ${ }^{39}$ Second, although it was noted that the exceptio found support in the doctrine and was often cited by States, particularly in the field of international

${ }^{32}$ ILC, 'Report of the International Law Commission on the Work of its $44^{\text {th }}$ session' (4 May-24 July 1992) UN Doc A/47/10 ('ILC Report 1992’) p. 23 para 151.

${ }_{33}$ Articles on the Responsibility of States for Internationally Wrongful Acts, with commentaries, Report of the ILC to the General Assembly on the work of its $53^{\text {rd }}$ session, ILCYB 2001-II ('Commentary to the ASR') p. 129 para 5.

${ }^{34}$ Special Rapporteur Crawford, Second report on State responsibility, Addendum 2, UN Doc A/CN.4/498/Add.2 ('Crawford II Add 2') para 323.

${ }^{35}$ Ibid, para 326.

${ }^{36}$ Ibid; see Case Concerning the Factory at Chorzów (Germany v Poland) (Jurisdiction) PCIJ Rep Series A No 17, p. 31; see also Gabč́kovo- Nagymaros Project (Hungary/ Slovakia) (Judgment) [1997] ICJ Rep 7 paras 107, 110; Art 80 United Nations Convention on Contracts for the International Sale of Goods (adopted in Vienna 11 April 1980, entered into force 1 January 1988) 1489 UNTS 3.

${ }^{37}$ Crawford II Add 2 para 329. See draft art 30bis.

${ }^{38}$ See Simma (A/CN.4/SR.2590 para 42); Pellet (ibid, para 63) and earlier Tomuschat (ILC, Summary Record of the $1896^{\text {th }}$ meeting, ILCYB 1985-I para 37). Contra Hafner (A/CN.4/SR.2590 para 53).

${ }^{39}$ Gaja (ibid, para 48); Pellet (ibid, para 63). 
economic law, ${ }^{40}$ it was considered that it would be dangerous to codify such a rule since it would give States the opportunity not to perform a synallagmatic obligation without having to go through the limitations on countermeasures. ${ }^{41}$ Given this mixed reception, Crawford, who had already expressed similar criticism for the broad form of the exceptio, ${ }^{42}$ did not press the draft article on the narrow form of the latter. ${ }^{43}$

Therefore, the principle of the exceptio non adimpleti contractus was not ultimately included in the VCLT as a legal basis for the non-performance of obligations arising from a treaty (though there was support for its inclusion by Special Rapporteur Fitzmaurice and by ILC members) nor in the 2001 Articles of the International Law Commission on the Responsibility of States for Internationally Wrongful Acts ('ASR') ${ }^{44}$ as a circumstance precluding wrongfulness; 'It could be said to have fallen between the two instruments'. ${ }^{45}$

2.3 Does the Notion of the Exceptio belong to the Law of Treaties or to the Law of State Responsibility?

Although the contrary view has also been expressed, namely that it is a countermeasure and therefore part of the law of State responsibility, ${ }^{46}$ the better view seems to be that the exceptio constitutes the exercise of a faculty inherent in a treaty, based on the interpretation of the latter, according to which a party to the treaty can withhold performance of synallagmatic obligations arising therefrom in case of their non-performance by the other party. ${ }^{47}$ This is one of the main reasons why the

${ }^{40}$ Hafner (A/CN.4/SR.2590 para 54).

41 Simma (ibid, para 45); Hafner (ibid, para 56). See also ILC Report 1999, p. 79 para 340; Crawford and Olleson (n 1) p. 74.

${ }^{42}$ Crawford II Add 2 para 329.

43 Special Rapporteur Crawford, Third report on State responsibility, Addendum 3, UN Doc A/CN.4/507/Add.3 ('Crawford III Add 3') para 366.

${ }^{44}$ ILC, Articles on the Responsibility of States for Internationally Wrongful Acts, Report of the ILC to the General Assembly on the work of its 53 ${ }^{\text {rd }}$ session, ILCYB 2001-II ('ASR').

${ }^{45}$ Crawford and Olleson (n 1) p. 56.

${ }^{46}$ Gaja (A/CN.4/SR.2590, p. 166 para 48); Hafner (ibid, para 53). In literature see Arnold McNair, The Law of Treaties (1961) p. 573, who however was not categorical; MM Gomaa, Suspension or Termination of Treaties on Grounds of Breach (1996) p. 13; Omer Yousif Elagab, The Legality of Non-forcible Counter-Measures in International Law (1988) pp. 45-6; Antonios Tzanakopoulos, Disobeying the Security Council: Countermeasures against Wrongful Sanctions (2011) p. 194. Caroline Laly-Chevalier, La violation du traité (2005) p. 421 considers that measures of reciprocity can be considered as part of both the law of treaties and the law of State responsibility.

${ }^{47}$ Separate Opinion of Judge Simma, FYROM v Greece para 20. For an instance of State practice see Austria, UNGA Sixth Committee ( $54^{\text {th }}$ Session) 'Report of the ILC on the work of its $51^{\text {st }}$ session' (20 December 1999) UN Doc A/C.6/54/SR.22 para 14. In the works of the ILC see Fitzmaurice IV, p. 
exceptio was not included in the ASR: ${ }^{48}$ the exception of non-performance was eventually seen as 'a specific feature of certain mutual or synallagmatic obligations and not a circumstance precluding wrongfulness', ${ }^{49}$ namely in the case of the exceptio the non-performance of the obligation is not wrongful and excused but State A is under no obligation to comply in the absence of State B's performance of the related obligation. ${ }^{50}$ Although the general rule of reciprocity could also apply with regard to customary international law obligations, ${ }^{51}$ it is arguable that the restriction of the notion of the exceptio to synallagmatic treaty obligations is in accordance with its origin in domestic contract laws ${ }^{52}$ and is explained by the concept that in synallagmatic obligations the performance by a party is the causa of the performance by the other. ${ }^{53}$ Therefore, the non-performance of a treaty obligation in response to non-performance of a synallagmatic obligation by the other party cannot be considered as an internationally wrongful act. Since the ASR codify the general rules on State responsibility, regardless of the conventional or customary origin of the international obligation breached, ${ }^{54}$ the exceptio (being associated with the law of treaties) could not be included among them. ${ }^{55}$

\subsection{The Relationship of the Exceptio With Other Responses to the Breach of a Treaty According to the VCLT and ASR}

The exceptio is distinct both from the termination and the suspension of the operation of a treaty in response to its material breach according to Art 60 VCLT and from countermeasures according to Arts 49 et seq ASR. ${ }^{56}$

66 para 82; Crawford III Add 3 paras 364, 366; ILC Report 1999, p. 79 para 341. For literature see Nisot (n 1) p. 668; Hugh Thirlway, "The Law and Procedure of the International Court of Justice 1960-1989” 63 BYBIL (1993) p. 41; Greig (n 1) pp. 399-400.

${ }^{48}$ James Crawford, State Responsibility: The General Part (2013) pp. 276-7.

${ }^{49}$ Commentary to the ASR, p. 72 para 9. Cf however FYROM v Greece para 161; Crawford (n 48) p. 679.

${ }^{50}$ See also Crawford III Add 3 para 364; Kabatsi (A/CN.4/SR.2591 para 12).

${ }^{51}$ See Fitzmaurice IV, p. 70 para 102.

52 See Section 4.2. Similarly Azaria (n 1) para 1.

${ }^{53}$ In domestic legal systems it is considered that, in synallagmatic obligations, the performance by the one party is the cause for the performance by the other (Henri Capitant, De la Cause des Obligations (1927) pp. 27-9; Crawford and Olleson (n 1) p. 72).

${ }^{54}$ Art 12 ASR.

55 See also Reuter (n 29).

${ }^{56}$ On the relationship between responses to the breach of a treaty see also Bruno Simma and Christian J Tams, "Reacting against Treaty Breaches", in DB Hollis (ed), The Oxford Guide to Treaties (2012) pp. 576-604; Malgosia Fitzmaurice, "Material Breach of Treaty: Some Legal Issues”, 6 ARIEL (2001) pp. 3-44. 
On the one hand, the exceptio operates as a defence and does not affect the legal force of the treaty, like termination or suspension according to Arts 70 (1)(a) and 72 (1)(a) VCLT. ${ }^{57}$ Therefore, it is not covered by Art 42 (2) VCLT, according to which 'the termination of a treaty... may take place only as a result of the application of the provisions of the treaty or of the present Convention [the VCLT]. The same rule applies to suspension of the operation of a treaty.' Moreover, the exceptio does not require a material breach, ${ }^{58}$ contrary to Art $60 \mathrm{VCLT}$, and it is restricted to synallagmatic obligations, while in Art 60 VCLT, in the event of partial termination or suspension of the operation of a treaty in response to its material breach, the provision which is terminated or the operation of which is suspended need not necessarily be the one which has been materially breached, but can be another provision of the same treaty. Furthermore, the exceptio does not seem to be submitted to procedural conditions, contrary to the cumbersome procedure of Arts 65-8 and Annex VCLT which is provided for Art 60 VCLT. ${ }^{59}$ Thus, although according to the analysis in the previous sections the exceptio belongs to the law of treaties, it is distinct from the termination of a treaty or the suspension of its operation according to Art 60 VCLT.

On the other hand, the exceptio is distinct from countermeasures, ${ }^{60}$ which are part of the law of State responsibility and are also a possible response to the breach of a treaty. Although it shares with countermeasures the legal character of a defence, it is again restricted to synallagmatic treaty obligations, contrary to countermeasures, ${ }^{61}$ which can be taken in response to the breach of any international obligation.

Of course, in practice it might not be easy to make the distinction, particularly among the various temporary measures in response to the breach of a treaty, such as the exceptio, the suspension of the operation of a treaty or countermeasures. ${ }^{62}$ It is true that if the exceptio is accepted in international law '...part of the function

\footnotetext{
57 See also Fitzmaurice II, 30 draft art 18 (2); Crawford (A/CN.4/SR.2590 para 44). For State practice see FYROM v Greece (Counter-Memorial of Greece) (19 January 2010) para 8.11. For literature see Zoller (n 8) pp. 27-8; Thomas Giegerich, 'Article 60', in O Dörr and K Schmalenbach (eds), Vienna Convention on the Law of Treaties, A Commentary (2012) p. 1043.

${ }^{58}$ See Section 3.

${ }^{59}$ See also Crawford II Add 2 para 325. For the conditions of application of the exceptio see also below Section 3.

60 Simma (A/CN.4/SR.2590 para 43).

61 Special Rapporteur Crawford, Second report on State responsibility, Addendum 4, UN Doc A/CN.4/498/Add.4 ('Crawford II Add 4') para 383.

${ }^{62}$ See also Crawford (n 48) pp. 675-6. See for example the Memorandum of the US Department of State Legal Adviser Davis Robinson on the application of the Treaty of Amity to expropriations in Iran, 13 October 1983 (1983) 22 ILM 1406, p. 1407.
} 
performed by countermeasures could be excluded, at least in the context of treaty relations. ${ }^{63}$ In fact, it might be argued that the responding State should, if the obligation breached is synallagmatic in relation to another, preferably resort to the exceptio non adimpleti contractus. If that 'would not constitute an adequate remedy, or would not be practicable' there could be resort to countermeasures, ${ }^{64}$ which are not restricted to the non-performance of synallagmatic obligations. Since it is restricted to the non-performance of synallagmatic obligations, the exceptio does not attract the criticism often associated with countermeasures; indeed, as Crawford has noted, 'a legal system might reject countermeasures, self-help other than in selfdefence and reprisals but still find a role for the exceptio. ${ }^{, 65}$

\section{The Question of the Conditions of Application of the Exceptio Non Adimpleti Contractus}

There is uncertainty regarding the conditions of application of the exceptio, as they have never been codified in an international instrument and no international court or tribunal has examined them in depth. However, elements for the identification of the conditions of application of the exceptio can be found in State practice, ${ }^{66}$ international case law and the works of the ILC on the basis of the notion of the exceptio in the domestic laws of many States. The following remarks might be made.

The exceptio non adimpleti contractus can be resorted to in case of any breach of a synallagmatic obligation arising from a treaty. A material breach is not required, ${ }^{67}$ although the exceptio could also apply in case of material breach, since nothing seems to preclude its application in such a case and since, as already mentioned, ${ }^{68}$ it is distinct from responses codified in Art 60 VCLT. Nonetheless, since a breach is required, it must be clarified that a restrictive interpretation of a treaty by a State party thereto following such an interpretation by another State party, which is not perceived by either party as a breach of that treaty, does not constitute an application

\footnotetext{
${ }^{63}$ Crawford and Olleson (n 1) p. 57.

${ }^{64}$ Fitzmaurice IV, p. 45, draft art 18 (1). See also Riphagen IV, p. 23 para 123. Cf Commentary to the ASR, p. 129 para 5.

${ }^{65}$ Crawford II Add 2 para 323.

${ }^{66}$ See below Section 4.1.

67 Fitzmaurice IV, p. 69 footnote 105, Case 3; Crawford II Add 2 para 325; FYROM v Greece (Counter-Memorial of Greece) (19 January 2010) para 8.28.

${ }^{68}$ See Section 2.4 .
} 
of the exceptio. ${ }^{69}$ However, it is arguable that the breach need not be an internationally wrongful act. ${ }^{70}$ As already stated, the exceptio only permits the nonperformance of an obligation synallagmatic to that which has not been performed by the defaulting party; moreover, there needs to be a connection between such nonperformances. ${ }^{71}$

Of course, the crucial question which arises is the definition of a synallagmatic obligation. Such an obligation has been described as one 'equivalent and corresponding' 72 to that breached; one which would 'correspond to, or [is] directly connected with, the obligation breached', ${ }^{73}$ in the sense that it is 'either a precondition or a concurrent condition to the performance of the same or a related obligation by the other party'. ${ }^{74}$

Whether such a relationship exists between two treaty obligations is a matter of treaty interpretation and obviously involves an important element of subjectivity, which is bound to create problems in the application of the exceptio. It may be that in some cases the identification of synallagmatic obligations will be an easy task, but in others the issue of whether a treaty obligation is 'corresponding' or 'equivalent' to another might create problems. For example, Greece claimed in the FYROM $v$ Greece case that ' ... what is synallagmatic is the agreement as such or as a whole, not the specific or individualized rights and obligations that flow from its provisions, ${ }^{75}$ which was disputed by FYROM. ${ }^{76}$ It may be pointed out that in the majority of State practice the application of the exceptio seems to be restricted to treaty obligations strictly corresponding to those which are not performed. ${ }^{77}$ Judge Bennouna in his declaration in the FYROM v Greece case has also supported a strict notion of

\footnotetext{
69 Special Rapporteur Riphagen, Sixth report on the content, forms and degrees of international responsibility, ILCYB 1985-II, p. 17 para 22, who considers this as a measure of retorsion; cf Reuter (ILC, Summary Record of the $1891^{\text {st }}$ meeting, ILCYB 1985-I para 8); Flitan (ILC, Summary Record of the $1893^{\text {rd }}$ meeting, ILCYB 1985-I para 3); see however Bartoš (UN Doc A/CN.4/SR.692 para 30). The distinction is also made by Sicilianos (Linos-Alexandre Sicilianos, Les Réactions Décentralisées à l' Illicite: Des Contre-mesures à la Légitime Défense (1990) pp. 39-40). See for example Répertoire Suisse de droit international public (Éditions S.A. Bâle 1975) Vol II, Chapitre 4, 870-1, Letter of the Swiss Federal Department of Justice and Police to the Federal Political Department, 6 July 1921, with regard to the 1882 France -Switzerland Treaty of Establishment, cited by Zoller (n 8) p. 15 footnote 40, who nevertheless considers it as application of the exceptio.

${ }^{70}$ See Capitant (n 53) p. 282, who notes that in domestic law no wrongfulness is required.

${ }^{71}$ FYROM v Greece para 161.

${ }^{72}$ Fitzmaurice IV, p. 46, draft art 20 (1).

${ }^{73}$ Riphagen V, p. 3, draft art 8.

${ }^{74}$ Crawford II Add 2 para 318.

${ }^{75}$ FYROM v Greece (Rejoinder of Greece) (27 October 2010) para 2.19.

${ }^{76}$ FYROM v Greece para 117.

${ }^{77}$ See Section 4.1.
} 
synallagmatic obligations. ${ }^{78}$ Besides, if it is accepted that the exceptio is not subject to procedural conditions of application, ${ }^{79}$ it needs to be as clear as possible what is the treaty obligation the breach of which gives rise to the exceptio: the content of the treaty obligations should be identical or their synallagmatic relationship should be as clear as possible, as not all obligations included in a bilateral treaty are necessarily in a synallagmatic relationship with each other. In short, the notion of synallagmatic obligations should be interpreted strictly.

Such synallagmatic obligations are by definition those based on reciprocity, namely reciprocal obligations arising from bilateral or multilateral treaties. ${ }^{80}$ It has been argued that the exceptio could apply also with regard to interdependent obligations, ${ }^{81}$ since the latter are characterised by a 'global reciprocity' ${ }^{82}$ Of course, questions arise in this regard: first, whether the notion of synallagmatic obligations could include interdependent obligations, even if the latter are also based on reciprocity; and, second, whether the exceptio would be an appropriate response to the breach of interdependent obligations in view of its conditions of application, particularly the lack of requirement of a serious character of the breach ${ }^{83}$ and the alleged lack of procedural conditions of application. Interdependent obligations create an 'all-or-nothing' ${ }^{84}$ structure in a multilateral treaty (for example a multilateral disarmament treaty), which perhaps should not be disturbed by application of the exceptio in the event of a minor breach. In State practice there does not seem to have been any instance of application of the exceptio with regard to interdependent obligations. Greig seems to correctly restrict the application of the exceptio in obligations 'contained in a bilateral treaty or in a multilateral instrument creating bilateral relationships. ${ }^{85}$ In any event, the exceptio certainly does not apply

\footnotetext{
${ }^{78}$ Declaration of Judge Bennouna, FYROM v Greece [2011] ICJ Rep 709.

79 See analysis below.

${ }^{80}$ For the classification of international obligations in reciprocal, interdependent or integral see Fitzmaurice II, pp. 30-1, draft arts 18 and 19.

${ }^{81}$ Azaria (n 1) para 1. Contra Riphagen VI, p. 12 draft arts 8 and 11 (1)(a), see however ibid, p. 13 para 6.

${ }^{82}$ Linos-Alexander Sicilianos, "The Classification of Obligations and the Multilateral Dimension of the Relations of International Responsibility” 13 EJIL (2002) p. 1135.

${ }^{83}$ Cf Art 60 (2)(c) VCLT, where a material breach is required, and Art 42 (b)(ii) ASR, which can be interpreted as requiring a breach of an interdependent obligation which is of a certain degree of seriousness ('the breach of the obligation...is of such a character') so as to radically change the position of all the other States to the treaty and to give rise to a response by any party to the treaty, even though in the ASR there is generally no distinction according to the character of the breach.

${ }^{84}$ Commentary to the ASR, p. 118 footnote 669.

${ }^{85}$ Greig (n 1) p. 381.
} 
with regard to integral obligations ${ }^{86}$ (the legal force of which is inherent and not dependent on a corresponding performance by the other parties to the treaty) particularly obligations arising from rules of jus cogens. ${ }^{87}$

The standing of the exceptio non adimpleti contractus does not present problems, as it is clear that the party to which the synallagmatic obligation is owed will be entitled to respond to its breach.

It has been argued that in the case of the exceptio the condition of reciprocity replaces that of proportionality. ${ }^{88}$ Although it is true that the strict reciprocity required by the exceptio to a great extent ensures proportionality, the better view seems to be that proportionality should also be applicable with regard to the exceptio, ${ }^{89}$ since reciprocity guarantees the qualitative but not necessarily the quantitative proportionality ${ }^{90}$ Proportionality is a general principle of law, ${ }^{91}$ which is therefore applicable both in the law of treaties, part of which is the exceptio, and in the law of State responsibility.

Lastly, it is not clear which the procedural conditions of the exceptio are. Riphagen did not clearly subject measures of reciprocity to procedural conditions; ${ }^{92}$ a similar position was taken by Arangio-Ruiz. ${ }^{93}$ There is support for the view that the exceptio is not subject to any procedural conditions. ${ }^{94}$ Indeed, in most instances

${ }^{86}$ Fitzmaurice IV, p. 46, draft art 20 (1); Crawford II Add 2 para 327. With regard to the nonapplicability of the principle of reciprocity in international human rights obligations see Ireland $v$ United Kingdom (1978) Series A no 25 para 239.

${ }^{87}$ Special Rapporteur Riphagen, Seventh report on State responsibility, ILCYB 1986-II ('Riphagen VII') p. 5 para 2; Crawford II, Add 2 para 327.

${ }^{88}$ FYROM v Greece (Counter-memorial of Greece) (19 January 2010) para 8.18; Azaria (n 1) para 14. However it must be noted that the response by Greece could not be considered as disproportionate to some of the breaches invoked.

${ }^{89}$ Mahiou (ILC, Summary Record of the $2280^{\text {th }}$ meeting, ILCYB 1992-I para 20); Arangio-Ruiz, (ILC Report 1992, p. 31 para 217).

90 Sicilianos (n 69) pp. 274-5; Claudia Annacker, 'Part Two of the International Law Commission’s Draft Articles on State Responsibility’, 37 GYIL (1994) p. 239; similarly LalyChevalier (n 46) p. 482.

${ }^{91}$ See Enzo Cannizzaro, Il principio della proportionalità nell' ordinamento internazionale (2000), especially pp. 450-4.

92 His relevant draft art 8 is not subject to draft art 10 on the procedural conditions of countermeasures (Riphagen VI, pp. 10-11). He nevertheless subjected also measures of reciprocity to his proposed compulsory dispute settlement mechanism for the implementation of international responsibility (ibid, p. 16 paras 14-7).

${ }_{93}$ Arangio-Ruiz III, p. 17 paras 50, 51, 58.

${ }^{94}$ Crawford III Add 3 para 364. See also Reuter (A/CN.4/SR.845para 26). For literature see Zoller (n 8) p. 126; Serena Forlati, "Reactions to Non-Performance of Treaties in International Law", 25:3 LJIL (2012) pp. 768-9, who nevertheless argues that while the procedural rules stipulated in the VCLT would certainly not apply to the exceptio, a notification of the intention to resort to it, analogous to the rule set forth by Art 52 (1)(b) ASR, might be an appropriate requirement. For State practice see FYROM v Greece (Counter-Memorial of Greece) paras 8.23, 8.26, on the basis of the character of the exceptio as a defence. In any case, Greece pointed to several situations in which it 
of State practice on the exceptio there does not seem to have been compliance with procedural conditions, as far as it could be ascertained. ${ }^{95}$ Nevertheless, given the fact that in State practice it has also been disputed that there is a response to the breach of a treaty, such as the exceptio, which is not submitted to procedural obligations, ${ }^{96}$ the conclusion is that there is still some uncertainty as to the procedural conditions of the exceptio, although there is stronger support for the view that it is not subject to procedural conditions.

Obviously, the conditions of application of the exceptio are less strict than those of the suspension of the operation of a treaty according to Art 60 VCLT and those of countermeasures. For this reason it has been argued that the exceptio presents the danger of evading the conditions of application of these two responses to the breach of a treaty according to the VCLT and ASR. ${ }^{97}$ This criticism is certainly justified to a certain extent, particularly since the conditions of application of the exceptio have not been adequately clarified on the basis of State practice by the ILC or in the international jurisprudence. Nevertheless, it could be argued, first of all, that the condition of the material character of the breach in Art 60 VCLT can also be evaded through resort to countermeasures and most of the procedural conditions of Art 60 included in Arts 65-8 and Annex VCLT are in any case not followed in State practice, ${ }^{98}$ as particularly with regard to the suspension of the operation of a treaty they can be considered as too strict; and second, that if the above mentioned restrictions on the conditions of application of the exceptio are accepted, particularly the application of the principle of proportionality, together with all the abovementioned prohibitions of resort to the exceptio, the main difference of the exceptio from countermeasures is the presumed lack of procedural conditions of application of the former. Of course, in many cases it is quite likely that a warning will already have been sent through diplomatic channels, since States are not willing to risk their

complained to FYROM about its failure to comply with its obligations under the Interim Accord (ibid, para 8.27). Besides, in domestic laws the exceptio is not submitted to procedural conditions (see Klöckner Industrie-Anlagen $\mathrm{GmbH}$ and others $v$ United Republic of Cameroon and Société Camerounaise des Engrais, ICSID Case No ARB/81/2, Award on the Merits, 21 October 1983, 114 ILR 152, p. 211 ('Klöckner v Cameroon (Award)’).

${ }^{95}$ See Section 4.1.

${ }^{96}$ FYROM v Greece (Reply of FYROM) (9 June 2010) para 5.52-3.

${ }^{97}$ See discussions in the ILC (Section 2.2); Separate Opinion of Judge Simma, FYROM v Greece [2011] ICJ Rep 695 para 22.

${ }^{98}$ Simma and Tams (n 56) pp. 593-4; Jan Klabbers, International Law (2 ${ }^{\text {nd }}$ ed., 2017) p. 70. 
friendly relations with other States, and in any case, as already pointed out, there is still some uncertainty with regard to the procedural conditions of the exceptio.

\section{Is the Exceptio non Adimpleti Contractus a Rule of Current International Law?}

Since the exceptio is distinct from both termination and suspension of a treaty according to Art 60 VCLT and countermeasures according to Arts 49 et seq ASR, and it is not included in either of these two instruments, the logical question which arises is whether it constitutes a rule of current international law. The ILC during its work on the law of State responsibility left the matter open by treating the exceptio as 'a specific feature of certain mutual or synallagmatic obligations and not a circumstance precluding wrongfulness'. ${ }^{99}$ Since it was not a circumstance precluding wrongfulness, it was not relevant to the law of State responsibility and therefore the ILC did not need to take a position on whether it was a rule of international law.

In fact, since the notion of the exceptio as a general response to the breach of a treaty is not incorporated in a treaty and therefore it does not fall within Art 38 (1)(a) of the Statute of the International Court of Justice ('ICJ Statute'), the question which arises is whether it derives its force as a rule of international law from the other sources of international law as reflected in Art 38 of the ICJ Statute, namely A. international custom, as evidence of a general practice accepted as law (Art 38 (1)(b)); B. the general principles of law (Art 38 (1)(c)); and/or C. subject to the provisions of Art 59 of the ICJ Statute, judicial decisions and the teachings of the most highly qualified publicists of the various nations, as subsidiary means for the determination of rules of law (Art 38 (1)(d)).

It is true that Art $60 \mathrm{VCLT}$ and Arts 49 et seq. ASR cover a great part of the scope of possible responses to the breach of a treaty. Nevertheless, if the exceptio is accepted as a rule of international law, it is still applicable on the basis of paragraph (8) of the preamble to the VCLT ${ }^{100}$ and Art 56 ASR. ${ }^{101}$

\subsection{Customary International Law}

\footnotetext{
99 See Summary Record of the $2704^{\text {th }}$ meeting, ILCYB 2001-I paras $10-14$.

100 See also Zoller (n 8) p. 18.

${ }^{101}$ FYROM v Greece (Rejoinder of Greece) (27 October 2010) para 8.10; Crawford III Add 3 para 366.
} 
In State practice from the $18^{\text {th }}$ to the early $20^{\text {th }}$ century there were several examples of application of the exceptio non adimpleti contractus. ${ }^{102}$ Of course, early treaties were mostly bilateral and therefore the obligations they contained had a strong synallagmatic character. Nevertheless, there seems to be more recent State practice in application of the exceptio.

First, such practice is reflected in the pleadings of States before international courts and tribunals and will be examined in the context of the relevant international case law. ${ }^{103}$ As it will be seen, this practice is inconclusive, as the invocation of the exceptio by one party to the case was often opposed by the other. To mention an example, in the Oil Platforms case the US invoked, inter alia, the exceptio as a response to an alleged breach by Iran of its reciprocal obligations under the 1955 Treaty of Friendship with the US. ${ }^{104}$ Notably, it was emphasised that the invocation of the 'fundamental principle of international law' of the exceptio is not limited by countermeasures or by the termination or suspension of the operation of the 1955 Treaty under the law of treaties; these were responses to which the US had not purported to resort. ${ }^{105}$ By contrast, in the same case Iran took the position that the exceptio has been codified in Art $60 \mathrm{VCLT},{ }^{106}$ namely that it did not retain a separate existence as a rule of international law. Nevertheless, there have been examples of such invocations by States or international organisations which have not been met with a clear objection by the other party or parties to the case: for instance, in its reply in the Canada-Certain Measures Affecting the Automotive Industry case before a WTO panel, the European Communities claimed that 'even in the absence of any express provision to that effect, it is implicit in any agreement involving mutual obligations that if one of the parties fails to fulfil its obligations, the other party is released from complying with its own obligations'. ${ }^{107}$ In a footnote, there was an express reference to the exceptio non adimpleti contractus and it was added that 'the

102 See Alexandre-Charles Kiss, Répertoire de la Pratique Française en Matière de Droit International Public (1962) Tome 1 paras 202-212, 215, 217-8. See also Chae Chan Ping v US 130 US 581 (1889) ('The Chinese Exclusion case') p. 601.

103 See below Section 4.3.1.

104 Mathias, Counsel for US, Oil Platforms (Islamic Republic of Iran v United States of America) (Merits) Oral Proceedings, 5 March 2003, CR 2003/18 paras 26.4, 26.7.

105 Ibid para 26.9.

106 Pellet, Counsel for Iran, Oil Platforms (Islamic Republic of Iran v United States of America) (Merits) Oral Proceedings, 3 March 2003, CR 2003/16 para 7.

107 WTO, Canada-Certain Measures Affecting the Automotive Industry-Report of the Panel (11 February 2000) WT/DS139/R and WT/DS142/R [7.187]. 
same principle finds expression' in Art 60 VCLT; namely, the exceptio was not identified with the regulation in Art 60 VCLT. ${ }^{108}$

Second, there are also some relevant examples in treaty practice. ${ }^{109}$ In many treaties, bilateral or bilateralisable, a provision is included which essentially stipulates that one of the parties to the treaty can withhold performance of an obligation for so long as the other/another party has not performed a synallagmatic obligation. Even if such treaty practice is not considered as extensive and uniform enough so as to give rise to customary international law, ${ }^{110}$ given also that most of these treaties are bilateral, ${ }^{111}$ it is nonetheless certainly a strong indication of relevant State practice. It could be argued that given the background of the exceptio in early State practice, such provisions, even if they do not constitute evidence of preexisting customary international law, ${ }^{112}$ could lead to the crystallisation of a rule of customary international law that has started to emerge prior to the conclusion of the treaty. ${ }^{113}$ It is true that the fact that States parties to such treaties decided to include therein a provision reflecting the exceptio might be considered as implying that they did not consider it as customary international law; however, it cannot be excluded that they inserted it for the purpose of legal certainty.

Third, there are statements by State organs accepting the application of the exceptio non adimpleti contractus as a response to the breach of a treaty. In 1990, the UK Minister for Public Transport stated that 'when a foreign country, in defiance of international convention, has decided to exclude our aircraft from its airspace, it is naturally assumed that that country's aircraft will be excluded from entering our air

108 Ibid, footnote 718 (emphasis added).

109 See for instance Art 3 (2) of the 1953 Convention on the International Right of Correction (435 UNTS 191), cited by Hans Blix and Jirina Emerson, The Treaty Maker's Handbook (1973) p. 137; Art XVI of the 1948 Agreement (with annex) respecting regular air services (Argentina and Netherlands) (95 UNTS 21); Art 10 of the 1959 Agreement concerning road transport (Netherlands and Italy) (484 UNTS 309); Annex II Art 6 of the 1982 Trade Agreement (Mexico and Costa Rica) (1398 UNTS 185); Art 6 of the 1993 Agreement on trade and economic relations (Lithuania and Russian Federation) (1950 UNTS 373). There are many further examples in similar types of treaties.

${ }^{110}$ See indicatively North Sea Continental Shelf (Federal Republic of Germany/Denmark; Federal Republic of Germany/Netherlands) [1969] ICJ Rep 3 paras 71-4; Art 38 VCLT. See also ILC, Report on the work of its $68^{\text {th }}$ session (2 May-10 June and 4 July-12 August 2016) p. 78 Draft Conclusion 11 (1)(c), 'ILC Report 2016’.

${ }^{111}$ Although bilateral treaties are not excluded from the identification of customary international law, but their impact has ‘to be approached with particular caution' (ILC, 'Report of the International Law Commission on the Work of its 67 ${ }^{\text {th }}$ session' (4 May- 5 June and 7 July-7 August 2015) p. 47 para 101.

112 Ibid, Sections 20-1; ILC Report 2016, p. 78 Draft Conclusion 11 (1)(a).

${ }^{113}$ Committee on Formation of Customary (General) International Law, Section 26 (c), ILC Report 2016, p. 78, Draft Conclusion 11 (1)(b). 
space'. ${ }^{114}$ No reference to suspension or countermeasures or to any procedural conditions was made; moreover, although bilateral air services treaties often contain a provision according to which a breach by a party entails corresponding nonperformance by the other party, this statement was not based on a relevant treaty provision. Consequently, it can be argued that such a measure would be considered as a natural application of the exceptio non adimpleti contractus.

Notably, the US in its comments to the draft articles of the ILC on State responsibility took the position that 'a state may also be entitled to reciprocal measures, which are outside [draft] article 30's definition of countermeasures.' ${ }^{\text {'15 }}$ However, there were also some statements by States in the Sixth Committee of the General Assembly on the work of the ILC on the law of State responsibility, which disputed the inclusion of the exceptio in the ASR or even its character as a response to the breach of a treaty. ${ }^{116}$

Fourth, there seem to have been actual responses by States to the breach of a treaty which correspond to the notion of the exceptio. The following section does not purport to be exhaustive, but is indicative of the fact that there are responses to breaches of synallagmatic treaty obligations which do not seem to fall within the notion of suspension of the operation of a treaty according to Art 60 VCLT or within the notion of countermeasures. Thus, they might be considered as application of the exceptio with regard to synallagmatic treaty obligations.

For example, on 21 June 1957 the United Nations Command in Korea considered that, in response to the alleged 'gross violations' of the provisions of subparagraph 13 (d) of the 1953 Armistice Agreement ${ }^{117}$ by China and North Korea, it was entitled

${ }^{114}$ UK Minister for Public Transport, Mr Michael Portillo, HC Deb 20 February 1990, vol 167, cols 171-3, cited in Geoffrey Marston, 'United Kingdom Materials on International Law 1990’ 61 BYBIL (1991) pp. 609-10.

115 'International Claims and State Responsibility’ (1991-9) Digest of US Practice Intl L Vol I, p. 1109.

116 See Spain, UNGA Sixth Committee ( $54^{\text {th }}$ Session) 'Report of the ILC on the work of its $51^{\text {st }}$ session’ (29 October 1999) UN Doc A/C.6/54/SR.21 para 19; Slovakia, UNGA Sixth Committee (54 ${ }^{\text {th }}$ Session) 'Report of the ILC on the work of its $51^{\text {st }}$ session' (1 November 1999) UN Doc A/C.6/54/SR.22 para 53, although it did not completely reject it. See also Topical Summary of the Discussion held in the Sixth Committee of the General Assembly during its $54^{\text {th }}$ session, on the ILC Report on the work of its $51^{\text {st }}$ session (1999) (UN Doc A/CN.4/504) para 52, where it was also pointed out, inter alia, that the exceptio appeared to be a primary rule. Japan took the view that the exceptio could be included within the notion of countermeasures, although it admitted that it was distinct from them (UNGA Sixth Committee $\left(54^{\text {th }}\right.$ Session) 'Report of the ILC on the work of its $51^{\text {st }}$ session' (1 November 1999) UN Doc A/C.6/54/SR.22 para 8).

${ }^{117}$ Agreement between the Commander-in-Chief, United Nations Command, on the one hand, and the Supreme Commander of the Korean People's Army and the Commander of the Chinese People's 
'to be relieved of corresponding obligations under the provisions of this subparagraph until such time as the relative military balance has been restored and... [China and North Korea], by its actions, has demonstrated its willingness to comply'. ${ }^{118}$ This appears to be an application of the exceptio, particularly since there was no reference to suspension of the relevant obligations of China and North Korea (thus it could not be considered as suspension of the operation of the Agreement) and there was no reference to countermeasures or, as the latter would probably be called at that time, 'reprisals'. ${ }^{119}$

In another case, Jordan issued in 1958 a decree excluding United Arab Republic (UAR) carriers from its territory, in response to the prohibition by the UAR of Jordanian planes from flying over or landing in the UAR. ${ }^{120}$ There was no reference to the suspension of a treaty as an instrument or to countermeasures and it seems that Jordan did not comply with any procedural conditions; at the same time, the obligation which was not performed can be considered as synallagmatic to that breached. Therefore this response seems to have taken place in application of the exceptio.

Even shortly before the conclusion of the VCLT, the Legal Adviser of the US Department of State in his brief of 4 March 1966 stated with regard to the increase of US military personnel and equipment in South Vietnam contrary to the provisions of the Geneva Agreements of $1954^{121}$ that there is an 'international law principle that a material breach of an agreement by one party entitles the other at least to withhold compliance with an equivalent, corresponding or related provision until the defaulting party is prepared to honor its obligation'. ${ }^{122}$ Although it refers to a material breach, and it has already been mentioned that in the case of the exceptio the breach need not be of a material character, this response seems to correspond to the notion of the exceptio. At least with regard to the case of corresponding provision it

Volunteers, on the other hand, concerning a Military Armistice in Korea, adopted at Panmunjom 27 July 1953, UN Doc S/3079 Annex A, p. 20.

${ }^{118}$ Communication dated 9 August 1957 from the representative of the United States of America to the United Nations, addressed to the Secretary-General, UN Doc A/3631, 4, cited by Sicilianos (n 69) p. 196.

119 It was noted that the relevant measures would enable the United Nations Command to 'take appropriate defensive counter-measures' (ibid, p. 3), but not that the non-performance was a countermeasure.

${ }^{120}$ Cited in Appeal Relating to the Jurisdiction of the ICAO Council (India v Pakistan) (Memorial of India) ICJ Pleadings 25, p. 249.

${ }^{121}$ Available at http://peacemaker.un.org/node/1477.

122 Cited by Quincy Wright, “The Termination and Suspension of Treaties” 61 AJIL (1967) p. 1000. Emphasis added. 
consists in the non-performance by the responding party of a treaty obligation synallagmatic to that breached; by contrast, according to Art 72 (1)(a) VCLT, in the event of suspension of the operation of a treaty in whole or in part, the parties, therefore not only the responding party, are released from the obligation to perform. It should be noted that there was no reference to the notion of countermeasures or to any procedural conditions of application which could support the view that such a response could be considered as a countermeasure.

However, there are also relevant examples after the conclusion of the VCLT. In 1970 the French Minister of Transport stated that the purported unlawful unilateral termination (therefore breach) by Italy of its 1962 Dimensions and Weights Agreement (with regard to vehicles) with France entailed a corresponding nonperformance by France; he did not refer to suspension, countermeasures, nor to any conditions of application. ${ }^{123}$

Therefore, even though this State practice, which seems to be accompanied by opinio juris, does not appear to be general enough in order to give rise to the creation of a rule of customary international law, ${ }^{124}$ it still indicates that the exceptio has not been absorbed by Art 60 VCLT and that it is not identified with countermeasures. It cannot be excluded that there could be in the future State practice in support of the view that the exceptio is also a rule of customary international law. In fact, it is very probable that there are more relevant examples of State practice, which- particularly given the alleged lack of procedural conditions of application of the exceptio- are not reported in collections of State practice.

\subsection{General Principles of Law}

The exception of non-performance (exception d' inexécution; Einrede des nicht erfüllten Vertrags) has significant background in domestic legal systems, as a defence to the non-performance of contractual obligations. ${ }^{125}$ It is recognised in the

\footnotetext{
${ }^{123}$ Réponse du ministre des transports à Q.E. Philibert, 8 April 1970, cited in Jean Charpentier, “Pratique Française de Droit International”, 16 AFDI (1970) pp. 994-5.

${ }^{124}$ Art 38 (1)(b) ICJ Statute; North Sea Continental Shelf (Federal Republic of Germany/Denmark; Federal Republic of Germany/Netherlands) [1969] ICJ Rep 3 para 77.

${ }^{125}$ On the comparative law background of the exceptio see more analytically Crawford and Olleson (n 1) pp. 66-73.
} 
contract law ${ }^{126}$ or in the jurisprudence ${ }^{127}$ of many countries around the globe. Moreover, although the Latin expression exceptio non adimpleti contractus is usually associated with civil law systems, ${ }^{128}$ in spite of terminological and other differences $^{129}$ it seems that the notion of the exception of non-performance can be found also in common law systems. ${ }^{130}$ The notion of the exceptio can also be traced in international commercial law instruments ${ }^{131}$ and has been considered as part of lex mercatoria. ${ }^{132}$

${ }^{126}$ See indicatively Europe: Section 320 German Civil Code; Art 1460 Italian Civil Code; Art 374 Greek Civil Code; Art 262 Dutch Civil Code; Art 82 Swiss Code of Obligations; Art 328 Russian Civil Code; Asia: Art 66-7 Contract Law of the People's Republic of China; Section 51 Indian Contract Act; Art 533 Japanese Civil Code; Art 247 UAE Civil Code; Art 191 Civil Code of Qatar; Africa: Art 104 Senegalese Code of Civil and Commercial Obligations; Art 163 Libyan Civil Code; America: American Uniform Commercial Code section 2-703 and American Law Institute, Restatement of the Law Second Contracts (1979) sections 234(1), 237 reflecting the same principle; Art 1235 Argentinian Civil Code; Art 1092 Brazilian Civil Code; Art 719 Paraguayan Civil Code. For some further examples see Azaria (n 1) para 28. In such cases, it does not matter whether the nonperformance is wrongful or not.

${ }^{127}$ As in the case of French law (see Barry Nicholas, The French Law of Contract (2 ${ }^{\text {nd }}$ ed., 1992) pp. 213-6). For writers see the seminal works by René Cassin, De l'exception tirée de l'inexécution dans les rapports synallagmatiques (1914) pp. 1-33; Capitant (n 53) pp. 261-320.

128 On the foundations of the principle in Roman law see Reinhard Zimmermann, The Law of Obligations, Roman Foundations of the Civilian Tradition (1990), p. 801 footnote 133.

${ }^{129}$ For example the fact that in common law there is no clear distinction between the termination of a contract and the exceptio (see GH Treitel, Remedies for Breach of Contract: A Comparative Account (1988) p. 245).

${ }^{130}$ For literature see Treitel (n 129) pp. 244-317, who refers to it as 'defence of refusal to perform' and observes that, although the notion has a civil law origin, it has 'functional equivalents' in common law systems (ibid, p. 312); Neil Andrews et al, Contractual Duties: Performance, Breach, Termination and Remedies ( $2^{\text {nd }}$ ed., 2017) p. 82, para 5-018; Jan M Smits, Contract Law: A Comparative Introduction (2014) p. 241. Cf however comments of Staughton LJ in Channel Tunnel Group Ltd v Balfour Beatty Construction Ltd [1992] 2 All ER 609, p. 616. Crawford and Olleson (n 1) p. 56 and analytically pp. 66-73 consider that the notion of the exceptio is better articulated in civil law systems and that it is not part of common law systems, on the basis that the latter produce similar results by contract interpretation and by the notion of conditional obligations. In the same vein Joshua Karton, "Contract Law in International Commercial Arbitration: the Case of Suspension of Performance” 58 ICLQ (2009), pp. 863-96, who however also notes that English courts do permit suspension of performance in certain circumstances and that the exceptio can be found in jurisdictions which are part of the English legal system but have a civil law origin, such as Scotland and South Africa (ibid p. 867): see in this regard Inveresk plc $v$ Tullis Russell Papermakers Ltd [2010] UKSC 19 [36], citing Corbett J in ESE Financial Services (Pty) Ltd v Cramer, 1973 (2) SA 805, p. 809 (cited by Robert P Barnidge Jr, Self-Determination, Statehood, and the Law of Negotiation: The Case of Palestine (2016) p. 133). See also n 126 for US Law.

${ }^{131}$ See Art 7.1.3 UNIDROIT Principles of International Commercial Contracts 2010; Art 9:201 Principles of European Contract Law 2002.

132 See ICC Case No 3540, French enterprise v Yugoslav subcontractor, Award of 3 October 1980, (1981) 4 JDI Clunet 914, p. 920; Philipp D O’Neill and Nawaf Salam, “Is the exceptio non adimpleti contractus part of the new lex mercatoria?”, in E Gaillard (ed), Transnational Rules in International Commercial Arbitration (1993) pp. 147-159. 
Therefore, given this strong comparative law background, the exceptio might be considered as a general principle of law ${ }^{133}$ in the sense of Art 38 (1)(c) ICJ Statute, with particular application in the law of treaties.

The problem of the function of general principles in public international law is beyond the scope of this article. It seems however to be generally acknowledged that an important function of general principles of law is to fill gaps in rules stemming from the other sources of international law. ${ }^{134}$ Therefore, if the exceptio is accepted as a general principle of law, it might applicable in order to fill possible gaps in responses to the breach of a treaty which are left by the VCLT or the ASR. ${ }^{135}$

Some of these gaps are mentioned below. A question which arises is the following: what is the response to the breach of a treaty which is not material, so that Art 60 VCLT cannot apply, while at the same time does not constitute an internationally wrongful act, so that countermeasures cannot either apply? No relevant provision exists either in the VCLT or in the ASR. If the victim State does not decide to ignore the breach altogether because of its minor importance, the gap created could, in the case of synallagmatic treaty obligations, be covered by the exceptio non adimpleti contractus, ${ }^{136}$ which, as already mentioned, does not require a material breach or an internationally wrongful act. In this way, the coherence among responses to the breach of a treaty is ensured.

Gaps can also be found in the regulation of the procedure for the termination or suspension of the operation of a treaty in response to its material breach in Arts 65-8 VCLT. According to Art 65 (1) VCLT, a party which, under the provisions of the VCLT, invokes a ground for terminating the treaty or suspending its operation must notify the other parties of its claim. Under Art 65 (2) VCLT, if, after the expiry of a

\footnotetext{
133 See also Section 4.3; Ripert (n 2) p. 606; Nisot (n 1) p. 669.

${ }^{134}$ With regard to this function of general principles see ILC, Conclusions of the work of the Study Group on the Fragmentation of International Law: Difficulties arising from the Diversification and Expansion of International Law, ILCYB 2006-II para 19(a); Hersch Lauterpacht, Private Law Sources and Analogies of International Law (1927) p. 71 and analytically pp. 60-71; Bing Cheng, General Principles of Law as applied by International Courts and Tribunals (1987) pp. 1-26; Alain Pellet, “Article 38", in A Zimmermann et al (eds), The Statute of the International Court of Justice: A Commentary ( $2^{\text {nd }}$ ed., 2012) pp. 850-3; Giorgio Gaja, "General Principles of Law”, MPEPIL online (last updated May 2013), available at http://opil.ouplaw.com/view/10.1093/law:epil/9780199231690/law-9780199231690e1410?rskey=Zp1QQj\&result=2\&prd=EPIL, accessed 18 April 2018, para 21.

135 Zoller (n 8) pp. 17-8; similarly Giegerich (n 57) p. 1043, who at the same time warns against upsetting the balance of interests embodied in Art 60 VCLT. Contra Filippo Fontanelli, "The Invocation of the Exception of Non-Performance: A Case-Study on the Role and Application of General Principles of International Law of Contractual Origin” 1:1 CJICL (2012) pp. 128-9.

${ }^{136}$ Forlati (n 94) p. 767.
} 
period which, except in cases of special urgency, will not be less than three months after the receipt of the notification, no party has raised any objection or where it does not reply to the claim, the party making the notification may carry out in the manner provided in Art 67 VCLT the measure which it has proposed. ${ }^{137}$ The phrase 'except in cases of special urgency' was intended 'to provide for cases of sudden and serious breach of a treaty which might call for prompt reaction by the injured party to protect itself from the consequences of the breach'. ${ }^{138}$ It can be argued that only temporary measures can be taken in case of urgency ${ }^{139}$ and not the termination of the treaty. However, there can also be no unilateral suspension of the operation of the treaty, since according to Arts 60 and 65-8 and Annex VCLT suspension is submitted to the same procedural conditions as termination. Therefore, cases of special urgency are precisely the ones in which urgent countermeasures according to Art 52 (2) ASR or the exceptio non adimpleti contractus are needed, the latter in case of synallagmatic treaty obligations, as they offer a prompt reply to the material breach without the need for the victim party to comply with strict procedural conditions. ${ }^{140}$ This is a case of complementarity between responses according to the VCLT, the ASR and even according to the exceptio, which may thus fill a gap in the regulation of the VCLT.

Moreover, the VCLT is silent on the question of the legal relations between the parties during the procedure of Arts 65-8 and Annex VCLT, namely whether the party or parties to the treaty invoking its material breach as a ground for its termination or suspension continue to be bound by their obligations under the treaty. In such a case, it is quite unlikely that the parties will agree on the provisional suspension of the treaty; therefore the treaty will most probably remain in force during the procedure. ${ }^{141}$ This may however be too cumbersome for the aggrieved party or parties: as the delegate of Uruguay, Jiménez de Aréchaga, noted during the first session of the Vienna Conference, such a solution 'disregarded the principle

137 The same requirement exists in case of termination or suspension in accordance with leges speciales contained in a treaty (Art 67 (2) VCLT).

${ }^{138}$ Waldock, UN Conference on the Law of Treaties, First Session (Vienna 26 March-24 May 1968) UN Doc A/CONF.39/11 ('Vienna Conference I’), p. 441 para 19.

139 Linos-Alexander Sicilianos, "The Relationship between Reprisals and Denunciation or Suspension of a Treaty" 4 EJIL (1993) p. 351.

${ }^{140}$ Nisot (n 1) pp. 672-3; Frederic L Kirgis Jr., "Some Lingering Questions about Article 60 of the Vienna Convention on the Law of Treaties” 22 Cornell International Law Journal (1989) p. 568.

${ }^{141}$ Waldock II, draft art 25 (6). 
inadimplenti non est adimplendum' ${ }^{142}$ Therefore, since the treaty remains in force, the non-defaulting State might take countermeasures ${ }^{143}$ or even resort to the exceptio, the latter in case of synallagmatic treaty obligations. ${ }^{144}$ These two responses enable the non-defaulting party not to perform during this procedure its obligations under the treaty which remain without counterpart.

In some of the above-mentioned cases, the exceptio has been referred to as an alternative to countermeasures, therefore it might be argued that it is not necessary for filling the relevant gaps. It might be envisaged though that the international legal system might reach a stage at which resort to countermeasures will be severely restricted or even prohibited; in such a case, should a party to a treaty be required to comply with its obligations which are synallagmatic to those which are not performed by the defaulting party until, for instance, an international organ is seized of the dispute?

In any case, notions which could be considered as general principles of law should perhaps not be discarded from the quiver of international law, as they might prove useful.

\subsection{Subsidiary Means}

\subsubsection{Judicial Decisions}

This section will examine the case law of international courts and tribunals concerning the exceptio. This principle has been advanced by States in their pleadings as a means of responding to the breach of a treaty alternative to the suspension of the operation of the treaty or its non-performance as a countermeasure. Nevertheless, with some exceptions, ${ }^{145}$ so far judicial or arbitral organs have not expressly applied it and it has been considered mainly in individual opinions of judges involved in the relevant cases.

\footnotetext{
142 Vienna Conference I, p. 356 para 38.

143 Fitzmaurice II, 32, draft art 20 (4); Ian Sinclair, The Vienna Convention on the Law of Treaties ( $2^{\text {nd }}$ ed., 1984) pp. 188-9.

${ }^{144}$ Nisot (n 1) pp. 672-3; Eduardo Jiménez de Aréchaga, "International Law in the Past Third of a Century” 159 Recueil des Cours de l’ Académie de Droit International (1978) p. 81; Giegerich (n 57) p. 1034.

145 See Sapphire International Petroleums Ltd. v National Iranian Oil Company; Klöckner v Cameroon (Award).
} 
The first case was the Meuse case brought before the PCIJ by the Netherlands against Belgium. Belgium in its Rejoinder had asked the Court, as an alternative to its other submissions, to declare that, by constructing certain works contrary to the terms of the 1863 Treaty ${ }^{146}$ between them concerning the regime of diversions of water from the river Meuse, the Netherlands had forfeited the right to invoke the Treaty against it. ${ }^{147}$ Therefore, Belgium invoked, though not explicitly, the exceptio non adimpleti contractus as a response to the alleged breach by the Netherlands. The PCIJ decided that there had been no breach of the Treaty by either Belgium or the Netherlands. ${ }^{148}$ Nevertheless, it noted that the Netherlands was not warranted in complaining of the construction and operation of a lock of which itself set an example in the past. ${ }^{149}$ This might be considered as an implicit acceptance of the force of the argument put forward by Belgium, based on the exceptio.

However, the principle found express support in two of the individual opinions attached to the decision. Judge Anzilotti in his Dissenting Opinion declared that the principle inadimplenti non est adimplendum ${ }^{150}$

...is so just, so equitable, so universally recognized that it must be applied in international relations also. In any case, it is one of these "general principles of law recognized by civilized nations" which the Court applies in virtue of Article 38 of its Statute. ${ }^{151}$

Judge Hudson in his Individual Opinion, referring to the principle of equity in common law as well as to civil law sources, also endorsed the exceptio non adimpleti contractus (albeit emphasising the need for its cautious application) and considered it as a general principle of law. ${ }^{152}$ It might be noted that the case in question concerned a bilateral treaty between the two parties and the relevant obligations were of a synallagmatic character. ${ }^{153}$

The applicability of the exceptio was also accepted in individual opinions of Judges of the ICJ, and more specifically by Judge de Castro in his Separate Opinions

146127 CTS 435.

147 The Diversion of Water from the Meuse (Judgment of 28 June 1937) PCIJ Rep Series A/B No 704 , p. 8.

148 Ibid, p. 32.

149 Ibid, p. 25.

${ }^{150}$ Nevertheless, seen in context, the statement refers to the exceptio non adimpleti contractus.

${ }^{151}$ Dissenting Opinion of Judge Anzilotti, ibid, p. 50.

${ }^{152}$ Individual Opinion of Judge Hudson, ibid, p. 77.

${ }^{153}$ Contra Separate Opinion of Judge Altamira, ibid, p. 43. 
in the Namibia ${ }^{154}$ and ICAO Council cases ${ }^{155}$ and by Judge Schwebel in his dissenting opinion in the judgement of the ICJ in the Nicaragua case. ${ }^{156}$

The exceptio was invoked expressly in the recent case between FYROM and Greece in 2011. In this case FYROM claimed that Greece had breached the 1995 Interim Accord between the Parties to the dispute. ${ }^{157}$ As an alternative to its main argument that it had complied with its obligations under the Interim Accord, Greece claimed that any failure to comply with its obligations could be justified, inter alia, on the basis of the exceptio non adimpleti contractus and it invoked a series of breaches of the Interim Accord by FYROM.

With regard to the exceptio, Greece took the position that it is a principle of general international law ${ }^{158}$ and that it is distinct from Art 60 VCLT $^{159}$ and rooted in the law of State responsibility and not in the law of treaties. ${ }^{160}$ However, in the oral proceedings it argued that the exceptio is reflected in both Art 60 VCLT and countermeasures. ${ }^{161}$ By contrast, FYROM argued that Art 60 VCLT provides a complete set of rules and procedures governing responses to material breaches under the law of treaties and that the exceptio is not recognised as justifying nonperformance under the law of State responsibility. ${ }^{162}$

The Court considered that Greece had failed to meet the minimum condition common to all three defences invoked by it, namely to demonstrate a connection between its response and any breach by FYROM, ${ }^{163}$ and that for this reason it was unnecessary for it to determine whether the doctrine of the exceptio non adimpleti contractus formed part of contemporary international law. ${ }^{164}$

\footnotetext{
${ }^{154}$ Separate Opinion of Judge de Castro, Legal Consequences for States of the Continued Presence of South Africa in Namibia (South West Africa) notwithstanding Security Council Resolution 276 (1970) (Advisory Opinion) [1971] ICJ Rep 170, p. 213.

155 Separate Opinion of Judge de Castro, Appeal Relating to the Jurisdiction of the ICAO Council (Judgment) [1972] ICJ Rep 116, pp. 128 footnote 1, 129.

156 Dissenting Opinion of Judge Schwebel, Military and Paramilitary Activities in and against Nicaragua (Nicaragua v United States of America) (Merits) [1986] ICJ Rep 259 paras 240, 269, who however does not distinguish it clearly from the 'clean hands' doctrine (see ibid, para 270).

1571891 UNTS 7. Application of the Interim Accord of 13 September 195 (the former Yugoslav Republic of Macedonia v Greece) ('FYROM v Greece') [2011] ICJ Rep 644 paras 12, 21.

${ }^{158}$ FYROM $v$ Greece (Rejoinder of Greece) para 8.9.

159 Ibid, para 8.6.

${ }^{160}$ Ibid, para 8.13.

${ }^{161}$ Pellet, Agent for Greece, FYROM v Greece, Oral Proceedings, 25 March 2011 at 15.00, CR 2011/10 para 39.

${ }^{162}$ FYROM v Greece (Reply of FYROM) (9 June 2010) para 5.7.

${ }^{163}$ FYROM v Greece para 123.

164 Ibid, para 161.
} 
However, the exceptio was examined by judges in their individual opinions. Judge Simma in his Separate Opinion criticised the Court for not going into the heart of the matter in order to clarify the legal status of the exceptio and its relationship with the other defences invoked by Greece. ${ }^{165}$ Although he did not seem to dispute the character of the exceptio as a general principle of law according to Art 38 (1)(c) of the ICJ Statute, ${ }^{166}$ he emphasised the dangers posed by its unilateral character ${ }^{167}$ and he took the position that Art 60 VCLT has exhaustively regulated the legal consequences of treaty breach, leaving no place for the exceptio. ${ }^{168}$

By contrast, Judge ad hoc Roucounas in his Dissenting Opinion, pointing out the support for the exceptio in the individual opinions of PCIJ and ICJ judges, took the position that the exceptio is a general principle of law according to Art 38 (1)(c) of the ICJ Statute which retains its separate existence: Art 60 VCLT does not deprive the injured party of the right to invoke the exceptio, particularly since it does not provide for every response to the breach of a treaty. ${ }^{169}$ Judge Bennouna in his Declaration also supported the applicability of the exceptio. ${ }^{170}$

This case signified the first time that the responding State invoked expressly and alternatively all three possible responses to the breach of a treaty: the exceptio as the response with the less strict conditions of application, countermeasures and the response with the strictest conditions of application, namely the suspension of the operation of the treaty. One of the main characteristics of this judgment is that the Court avoided dealing with the relationship between these three responses to treaty breaches and also more specifically with the question of whether the exceptio is a rule of international law; however, there was a stark contrast of views on this issue, reflected in the separate opinions of Judges of the case.

The exceptio, referred to as principle of reciprocity, was also invoked by Judge Ameli in his dissenting opinion in the INA Corporation $v$ Iran award of the Iran-US Claims Tribunal, ${ }^{171}$ who interestingly considered that it applies 'by operation of general public international law, irrespective of whether or not it is a term of the

\footnotetext{
165 Separate Opinion of Judge Simma, FYROM v Greece [2011] ICJ Rep 695 para 6.

166 Ibid, para 12.

167 Ibid, para 13.

168 Ibid, paras 21, 22, 29.

${ }^{169}$ Dissenting Opinion of Judge ad hoc Roucounas, FYROM v Greece [2011] ICJ Rep 720 para 29.

${ }^{170}$ Declaration of Judge Bennouna, FYROM v Greece [2011] ICJ Rep 709 (ibid, 1).

${ }^{171}$ INA Corporation v Iran (1985) 8 Iran-USCTR 373, pp. 432-441, cited by Laly-Chevalier (n 46)
} p. 416. 
relevant treaty or other agreement'. ${ }^{172}$ In other words, he seemed to consider it as customary international law.

Nevertheless, there have been cases in which international courts or tribunals have impliedly or expressly referred to the exceptio. Apart from the obiter dictum of the PCIJ in the Meuse case, there was implied reference to the exceptio in the Air Services Agreement arbitral award. The US response to the alleged breach of the Air Services Agreement by France could be considered as application of the exceptio, since in its Memorial the US described its response as '.... limited withdrawal of rights of French carriers corresponding to the rights denied the United States carrier'. ${ }^{173}$ Nevertheless, the US in its Memorial invoked expressly in justification of its action only countermeasures and their conditions of application, namely proportionality and the procedural conditions, therefore the Tribunal examined only the defence of countermeasures. It should be noted though that the Tribunal referred to the possibility that the measure at issue could 'bear on a simple principle of reciprocity measured in economic terms, ${ }^{174}$ which appears to be a reference to the notion of the exceptio.

In another context, in the Application of the 'IMESI' (Internal Specific Tax) to the Trade in Cigarettes case, Uruguay invoked the exceptio against Paraguay. Nevertheless, the ad hoc MERCOSUR arbitral tribunal in its award seemed to confuse it with Art 60 VCLT in requiring a material breach; moreover, it expressed reservations with regard to its application in international law, particularly in multilateral treaties establishing regional integration organisations, creating a common market. ${ }^{175}$ It is true that it is doubtful that the exceptio could apply in such treaties, as it has also been accepted with regard to the treaties establishing the EU; ${ }^{176}$ nevertheless, this does not preclude its application in bilateral or bilateralisable treaties creating synallagmatic obligations. Similarly, although Argentina seems to have invoked the exceptio in the Argentina-Poultry Anti-

\footnotetext{
172 Ibid, p. 434.

${ }^{173}$ Air Service Agreement of 27 March 1946 between the United States of America and France case (hereinafter 'Air Services Agreement') (1978) 18 RIAA 417 para 18.

174 Ibid, para 78.

175 Laudo VIII del Tribunal Arbitral "Ad Hoc" del MERCOSUR constituido para decidir en la controversia entre la República del Paraguay a la República Oriental del Uruguay sobre la "Aplicación del "IMESI" (Impuesto Específico Interno) a la Comercialización de Cigarrillos", $\quad 21 \quad$ May 2002 <http://www.mercosur.int/msweb/portal\%20intermediario/es/controversias/arquivos/VIII\%20LAUD O.pdf $>$, pp. 6-7, accessed 18 April 2018.

${ }^{176}$ Case 26/62 Van Gend en Loos v Nederlandse Administratie der Belastinghen [1963] ECR 1, 12.
} 
dumping Duties case, by arguing, inter alia, that other members of the WTO had been engaging in the conduct of which it was accused, the WTO Panel seems to have rejected this argument by stating that the dispute before it concerned only Argentina's conduct. ${ }^{177}$ It has been argued that the exceptio has no place in a multilateral treaty such as that establishing the WTO, 'since this principle has, unless explicitly agreed otherwise, its place in bilateral contractual relationships only., ${ }^{178}$

Lastly, several international arbitral tribunals have applied or accepted the applicability of the exceptio as a general principle of law; although they did not strictly deal with it as a response to the breach of a treaty.

For instance, there was application of the exceptio in the Sapphire International Petroleums Ltd. v National Iranian Oil Company arbitral award. ${ }^{179}$ The applicable law in the case were 'the principles of law generally recognized by civilized nations ${ }^{180}$ and the arbitrator took the view that the exceptio is such a principle, which is to be found both in civil and common law. ${ }^{181}$

Moreover, there was express reference to and application of the exceptio by an ICSID tribunal in the Klöckner $v$ Cameroon case. The Tribunal applied the exceptio in favour of the respondent State as a ground for the termination of the obligation, considering it as a general principle of law. ${ }^{182}$ However, the award was later annulled by a decision of the Ad Hoc Committee, which took the view that the exceptio has instead a suspensive effect and which did not apply the exceptio in the case. $^{183}$

There were also other ICSID tribunals accepting, in principle, the applicability of the exceptio in the relevant cases ${ }^{184}$ as well as a tribunal in an ad hoc arbitration

177 WTO, Argentina- Definitive Anti-Dumping Duties on Poultry from Brazil- Report of the Panel (22 April 2003) WT/DS241/R [7.79].

${ }_{178}$ Mitsuo Matsushita et al (eds), The World Trade Organization: Law, Practice, and Policy (3 ${ }^{\text {rd }}$ ed., 2015) p. 62.

179 Sapphire International Petroleums Ltd v National Iranian Oil Company (Arbitral Award) (1963) 35 ILR 136, pp. 181-5, cited by Laly-Chevalier (n 46) p. 418.

180 Ibid, p. 175.

${ }^{181}$ Ibid, pp. 182 and references therein, 183.

182 Klöckner v Cameroon (Award), 114 ILR 152, pp. 210-2, examining French, English and international law. However, that decision involved the law of a State and not, directly, international law (ILC Report 1999, p. 78 para 335).

${ }^{183}$ Klöckner v Cameroon, Decision by the Ad Hoc Committee on the Application for Annulment by Klöckner, 3 May 1985 paras 170-1.

184 See, indicatively, Azurix Corporation v Argentine Republic, ICSID Case No ARB/01/12, Award, 14 July 2006 para 260; Compañía de Aguas del Aconquija S.A. and Vivendi Universal S.A. v Argentine Republic, ICSID Case No ARB/97/3, Award rendered after resubmission proceeding, 20 August 2007 para 7.5.28. 
under UNCITRAL rules. ${ }^{185}$ This was done on the basis that the exceptio constitutes a general principle of law. Nevertheless, in the Yukos case, although the respondent invoked the exceptio, the Tribunal constituted under Art 26 of the Energy Charter Treaty and the 1976 UNCITRAL Arbitration Rules did not examine its application in the case, merely by noting its rejection by Judge Simma in his Separate Opinion in the FYROM $v$ Greece case ${ }^{186}$ and without conducting any examination of the position of the principle in international law.

In conclusion, there is uncertainty with regard to the position of the exceptio non adimpleti contractus in international law also in the international jurisprudence. It has only been expressly relied on by two international tribunals (Sapphire International Petroleums Ltd. v National Iranian Oil Company and Klöckner v Cameroon (Award)). Of course, both awards concerned investor-State arbitration in which applicable law were general principles of law and which did not strictly involve the breach of a treaty. Furthermore, the legal nature of the exceptio, its relationship with other temporary responses to the breach of a treaty and its conditions of application have not been adequately clarified in the international jurisprudence. Nonetheless, it must be stressed that the exceptio is a response which has for long been invoked before international courts and tribunals and has never been expressly rejected by them. In fact, it has found implied support by the PCIJ in the Meuse case and by the arbitral tribunal in the Air Services Agreement case; moreover, with the exception of the separate opinion of Judge Simma in the FYROM $v$ Greece case, it has found support in individual opinions of several PCIJ and ICJ judges (although admittedly some of the ICJ judges did not distinguish it clearly from the general principle inadimplenti non est adimplendum or from other doctrines, such as the clean hands doctrine). Lastly, although a considerable number of arbitral tribunals have in principle accepted the applicability of the exceptio non adimpleti contractus in investment arbitration, following the separate opinion of

185 Eureko BV v Republic of Poland, Partial Award, 19 August 2005 paras 176-184, without however applying it in the case on the ground that it did not concern simultaneous or conditional performance. It must be noted however that the Tribunal reserved its position with regard to 'whether the exception of non-performance is a maxim of interpretation or a rule of international law' (ibid, para 177). For relevant awards of the International Chamber of Commerce see Karton (n 130) pp. 885-94.

186 Yukos Universal Ltd. (UK- Isle of Man) v Russian Federation, PCA Case No AA 227, UNCITRAL (Energy Charter Treaty), Final Award, 18 July 2014 para 1360. Similarly in the Veteran Petroleum Ltd (Cyprus) v Russian Federation, PCA Case No AA 228, Final Award, 18 July 2014 para 1360; Hulley Enterprises Ltd v Russian Federation, PCA Case No AA 226, Final Award, 18 July 2014 para 1360. 
Judge Simma in the FYROM $v$ Greece case some arbitral tribunals have disputed the continuing existence of the exceptio in international law, without expressly denouncing it. Most international courts or tribunals have considered it as a general principle of law, although the tribunal in Eureko $v$ Poland reserved its position as to whether it is a maxim of interpretation or a rule of international law; it must be noted though that a view has been expressed (INA Corporation $v$ Iran) that it also constitutes part of customary international law.

Therefore, the international jurisprudence as a subsidiary means for the determination of a rule of international law does not clearly support or refute the proposition that the exceptio non adimpleti contractus is a rule of customary international law, which can be invoked in response to the breach of a treaty alternatively to Art 60 VCLT or countermeasures; nevertheless, it offers clear support for the view that it constitutes a general principle of law.

\subsubsection{Teachings of the Most Highly Qualified Publicists of the Various Nations}

Many authors have referred to the exceptio in their analyses of responses to the breach of a treaty, ${ }^{187}$ most of them considering it as a general principle of law. ${ }^{188}$ The same position has been taken, as already seen, by several members of the ILC. The view has also been supported that the exceptio is both a general principle of law and part of customary international law. ${ }^{189}$ Several authors have clearly distinguished it from the responses codified in Art $60 \mathrm{VCLT} ;{ }^{190}$ and it has been pointed out that the exceptio is a way to overcome the restriction of Art 60 VCLT to material breaches of

\footnotetext{
${ }^{187}$ Apart from the authors already cited in the previous analysis, see indicatively Emer De Vattel, The Law of Nations, or Principles of the Law of Nature, Applied to the Conduct and Affairs of Nations and Sovereigns (1758, reprinted 2008) [202]; Christian Wolff, Jus Gentium Methodo Scientifica Pertractatum (1749 reprinted 1964) [432]; McNair (n 46) p. 540, who refers to 'retaliatory suspension of performance of corresponding provision of a treaty'; Jiménez de Aréchaga (n 144) p. 81; Paul Reuter, Droit international public (1976) p. 131; Kirgis (n 140) p. 558; Sicilianos (n 69) pp. 287-8 (cf ibid, pp. 36-40); Thirlway (n 47) p. 41, but cf Hugh Thirlway, The sources of international law (2014) p. 101, where the author does not seem to distinguish between the exceptio and the principle inadimplenti non est adimplendum; Alain Pellet and Alina Miron, "Sanctions” MPEPIL online (last updated August 2013) http://opil.ouplaw.com/view/10.1093/law:epil/9780199231690/law-9780199231690e984?rskey=k2aLrK\&result=1\&prd=EPIL $>$ para 4, accessed 18 April 2018. Judge Simma in his earlier writings also accepted the exceptio as a response to the breach of a treaty (see Bruno Simma, “Termination and Suspension of Treaties: Two Recent Austrian Cases” 21 GYIL (1978) p. 85).

${ }^{188}$ See for example Nisot (n 1) p. 669; Greig (n 1) p. 399.

189 Giegerich (n 57) p. 1043, who nevertheless considers that Art 60 VCLT codifies and circumscribes the exceptio.

190 See for instance Greig (n 1) pp. 320-1.
} 
a treaty. ${ }^{191}$ Certainly, some of these publicists, representing various nationalities and legal traditions, can be considered as ranking among the most qualified publicists of the various nations. Of course, there are also other publicists, apart from those who have already been referred in the context of the ILC discussions, who do not seem to include the exceptio among possible responses to the breach of a treaty ${ }^{192}$ or who note the uncertainty regarding the status of the exceptio. ${ }^{193}$ Some of those again can be considered as among the most qualified publicists of the various nations. Therefore, again, this subsidiary source does not clarify the issue whether the exceptio can be considered as a rule of international law. Nevertheless, it is to be noted that an important number of publicists seem to accept the exceptio non adimpleti contractus as a general principle of law and as a possible response to the breach of a treaty.

\section{Conclusion}

The exceptio non adimpleti contractus has escaped the codification of the ILC both in the law of treaties and in the law of State responsibility, although in both cases there were proposals for its inclusion, either by Special Rapporteurs or by members of the ILC. Nevertheless, it should generally be accepted that it is a defence to the breach of a treaty which belongs to the law of treaties and which is distinct from both the termination and the suspension of the operation of a treaty according to Art 60 VCLT and from countermeasures according to Arts 49 et seq ASR. There is still uncertainty with regard to its conditions of application, although its background in domestic contract laws, State practice and the works of the ILC offer some indications: it is restricted to the case of breach of synallagmatic treaty obligationsthe synallagmatic character of which should be interpreted strictly- arising from bilateral or bilateralisable treaties; it is prohibited in cases of breach of integral (and arguably also of interdependent) treaty obligations; the principle of proportionality is

191 Gerhard Hafner, “The Drawbacks and Lacunae of the VCLT”, in G Hafner et al (eds), Völkerrecht und die Dynamik der Menschenrechte: Liber Amicorum Wolfram Karl (2012) pp. 421, 431.

192 See for instance Daniel P O’Connell, International Law (1970) Vol I, pp. 266-8; Ian Brownlie, Principles of Public International Law (7 $7^{\text {th }}$ ed., 2008) pp. 622-3; James Crawford, Brownlie's Principles of Public International Law (8 ${ }^{\text {th }}$ ed., 2012) pp. 391-2; Malcolm N Shaw, International Law

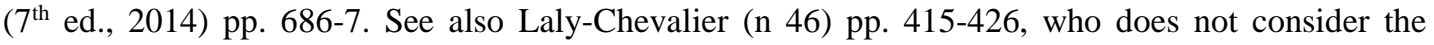
exceptio as a rule of international law.

${ }^{193}$ Crawford (n 48) p. 678. 
also applicable; and there do not seem to be procedural conditions attached to it. Of course, if it is accepted as a rule of international law, the conditions of application of the exceptio need to be clarified on the basis of State practice by an authoritative international organ.

On the question of whether the exceptio constitutes a rule of current international law, there is overwhelming support for the view that the exceptio constitutes a general principle of law in the sense of Art 38 (1)(c) ICJ Statute, given the extensive comparative law background of the notion in domestic contract laws as well as the acceptance of the exceptio as a general principle of law in the case law of international courts and tribunals and by the greatest part of the doctrine. As such, as pointed out in this article, the exceptio can fill gaps in the regulation of responses to the breach of a treaty by the VCLT and ASR. Besides, if it is accepted that the nonperformance of a treaty obligation which is synallagmatic to that breached is not an internationally wrongful act, its justification on the basis of countermeasures is conceptually problematic.

There is uncertainty as to whether the exceptio constitutes a rule of customary international law, although this article has shown that there is State practice on the matter which is not negligible and which seems to be combined with the element of opinio juris. Nevertheless, given also the existence of some pleadings or declarations by States which dispute the character of the exceptio as a rule of international law, such practice does not seem to be sufficiently widespread and systematic so as to give rise to a rule of customary international law under Art 38 (1)(b) ICJ Statute. In any event, such State practice shows that it is doubtful that the exceptio has been absorbed by either Art 60 VCLT or countermeasures. International jurisprudence and doctrine do not clearly support nor refute the argument that the exceptio is a rule of customary international law, although there is some implicit acceptance in the jurisprudence and an important part of the doctrine seems to consider it as a possible response to the breach of a treaty.

This article does not dispute that the exceptio, as a possible unilateral response to the breach of a treaty, bears risks for treaty stability; nevertheless, it is arguably also a response pertinent to the nature of synallagmatic obligations. Such risks could perhaps be mitigated through clarification and restriction of its conditions of application instead of its rejection per se. 